\title{
Genetic Structure of Populations of Rhizoctonia solani Anastomosis Group-1 IA from Soybean in Brazil
}

\author{
M. B. Ciampi, M. C. Meyer, M. J. N. Costa, M. Zala, B. A. McDonald, and P. C. Ceresini
}

First author: UNESP, Universidade Estadual Paulista, Campus de Jaboticabal, Graduate Program in Genetics and Plant Breeding, Jaboticabal, SP, Brazil; second author: Embrapa Soja, Balsas, MA, Brazil; third author: Fundação Rio Verde, Lucas do Rio Verde, MT, Brazil; fourth, fifth, and sixth authors: Plant Pathology, Institute of Integrative Biology, ETH Zurich, Switzerland; and sixth author: UNESP, Campus de Ilha Solteira, Dept. de Fitossanidade, Engenharia Rural e Solos, 15385-000, Ilha Solteira, SP, Brazil. Accepted for publication 11 April 2008.

\begin{abstract}
Ciampi, M. B., Meyer, M. C., Costa, M. J. N., Zala, M., McDonald, B. A., and Ceresini, P. C. 2008. Genetic structure of populations of Rhizoctonia solani anastomosis group-1 IA from soybean in Brazil. Phytopathology 98:932-941.

The Basidiomycete fungus Rhizoctonia solani anastomosis group (AG)-1 IA is a major pathogen of soybean in Brazil, where the average yield losses have reached 30 to $60 \%$ in some states in Northern Brazil. No information is currently available concerning levels of genetic diversity and population structure for this pathogen in Brazil. A total of 232 isolates of $R$. solani AG1 IA were collected from five soybean fields in the most important soybean production areas in central-western, northern, and northeastern Brazil. These isolates were genotyped using 10 microsatellite loci. Most of the multilocus genotypes (MLGTs) were site-specific, with few MLGTs shared among populations. Significant population

subdivision was evident. High levels of admixture were observed for populations from Mato Grosso and Tocantins. After removing admixed genotypes, three out of five field populations (Maranhao, Mato Grosso, and Tocantins), were in Hardy-Weinberg (HW) equilibrium, consistent with sexual recombination. HW and gametic disequilibrium were found for the remaining soybean-infecting populations. The findings of low genotypic diversity, departures from HW equilibrium, gametic disequilibrium, and high degree of population subdivision in these $R$. solani AG-1 IA populations from Brazil are consistent with predominantly asexual reproduction, short-distance dispersal of vegetative propagules (mycelium or sclerotia), and limited long-distance dispersal, possibly via contaminated seed. None of the soybean-infecting populations showed a reduction in population size (bottleneck effect). We detected asymmetric historical migration among the soybean-infecting populations, which could explain the observed levels of subdivision.
\end{abstract}

The Basidiomycete fungus Thanatephorus cucumeris (anamorph = Rhizoctonia solani) anastomosis group (AG)-1 IA is considered a major pathogen affecting important crops worldwide, including rice, maize, and soybean $(8,31)$. On soybeans $R$. solani AG-1 IA causes leaf blight, one of the most devastating diseases on a global basis. The average yield losses caused by the fungus in Brazil were reported to reach 30 to $60 \%$ in states where the environmental conditions are favorable for the pathogen, such as Maranhão, Mato Grosso, Pará, and Tocantins States $(66,70)$. In the United States, yield losses caused by Rhizoctonia foliar blight on soybean can reach 30 to $45 \%$ in Louisiana (69).

The control strategies for this disease are limited. Fungicide applications are the primary means for disease management. Strobilurins are widely used to control both foliar blight and leaf rust (Phakopsora pachyrhizi) on soybeans, which may lead to the evolution of fungicide resistance $(47,48)$. There are no resistant varieties commercially available. Breeding soybean with resistance to leaf blight is difficult because resistance is quantitative and its inheritance is still not understood $(41,48)$.

Knowledge of the genetic structure of pathogen populations can be used to infer their life histories and the evolutionary processes that shape pathogen populations in agroecosystems

\section{Corresponding author: P. C. Ceresini; E-mail address: paulo.ceresini@agrl.ethz.ch}

* The $e$-Xtra logo stands for "electronic extra" and indicates that the online version contains four extra files showing the geographical locations of populations, the allele frequency distributions and the information content associated with the ten microsatellite loci, and the multilocus microsatellite genotypes of the pathogen. Figure 1 appears in color online.

doi:10.1094/PHYTO-98-8-0932

(c) 2008 The American Phytopathological Society
(44). Analysis of the distribution of genetic diversity within and among populations can be used to identify patterns of migration (6) and to reveal cryptic recombination (37). A high degree of similarity or the detection of rare alleles shared between geographically separated populations provide evidence for gene flow between them, with possible implications for the effectiveness of control strategies (44). Knowledge of the genetic structure of pathogen populations is hypothesized to offer insight into their future evolutionary potential, which could be useful to optimize the management of resistance genes and fungicides in agriculture $(44,45)$.

Population genetic analyses can also be used to make inferences about the mode of reproduction, e.g., to assess the relative contributions of asexual and sexual reproduction in pathogen populations (37). Through sexual reproduction recombinant genotypes are produced, maintaining higher genotype diversity in sexual populations when compared to asexual populations that may have the same gene diversity. Another effect of frequent recombination on population structure is the random association of alleles at different loci, such that gametic genotype frequencies are approximately equal to the products of the frequencies of the alleles that define each genotype. Deviations from the expected frequencies lead to gametic disequilibrium (or linkage disequilibrium) that can be detected with statistical tests (37).

$R$. solani is thought to be primarily asexual, disseminating and surviving as vegetative mycelium and sclerotia (1). R. solani AG1 IA on soybean is unique because it is thought to have an active sexual cycle. Basidiospore-bearing hymenia are commonly observed in soybean fields and are thought to play an important epidemiological role (31). However it is currently unknown whether recombination occurs in field isolates and whether AG-1 IA is homothallic or heterothallic (57). Although meiotic ba- 
sidiospores are detected in some cases, the detection of mating reactions and their effects on population structure are not easy to determine in vitro for most of the $R$. solani AGs (14). Homokaryons of $R$. solani cannot be distinguished from heterokaryons due to the multinucleate condition of $R$. solani hyphae and its lack of clamp connections. In contrast to isolates of most AGs, AG-1 IA readily sporulates in vitro (21) allowing for genetic analysis of basidiospore progeny and the detection of recombination.

There is no information currently available regarding the population structure of $R$. solani AG-1 IA on soybean in Brazil. Earlier studies on genetic variation of $R$. solani AG-1 IA from soybean focused mostly on genetic differences among isolates obtained from different areas. Using random amplified polymorphism DNA (RAPD) and rDNA-internal transcribed spacer 1 (ITS) sequences, preliminary studies provided evidence for high genetic diversity in populations of AG-1 IA from soybean $(22,23)$. High haplotype diversity for ITS-5.8S rDNA was detected among Brazilian isolates of the pathogen from soybean. While 16 ITS haplotypes were found among 32 soybean-infecting isolates, only one ITS haplotype was detected among 20 rice-infecting isolates originating from different continents. The most probable ancestral haplotype was postulated to have originated either from Mato Grosso or Maranhão States (10).

Several important questions about the genetic structure of $R$. solani AG-1 IA populations in Brazil remain unanswered. (i) Are geographic populations of $R$. solani AG-1 IA genetically subdivided or does gene flow occur freely throughout Brazil? (ii) What is the level of gene flow among these populations? (iii) Are these populations clonal or panmictic? The aims of our study were (i) to measure gene and genotype diversity in $R$. solani AG-1 IA populations infecting Brazilian soybeans; (ii) to describe the hierarchical genetic structure within and among $R$. solani AG-1 IA populations; (iii) to infer the predominant reproductive mode in these populations. We tested the null hypotheses that geographical populations of $R$. solani AG-1 IA are genetically homogenous (hence nonsubdivided or differentiated) and that these populations are sexually recombining in structure.

\section{MATERIALS AND METHODS}

Population sampling. A Brazilian sample of five field populations comprising a total of 232 isolates of Rhizoctonia solani AG-1 IA was collected from naturally infected commercial soybean fields in three states, in Central-western (Mato Grosso, MT), Northern (Tocantins, TO), and Northeastern Brazil (Maranhão, MA). These locations represent the most important soybean production areas, as described in Table 1. The first two populations (MT98, MA00) were collected in 1998 and in 2000 from sites that were approximately $1,500 \mathrm{~km}$ apart. In 2006, three additional populations were sampled; two of them were from different sites (MT06 and TO06) and one (MA06) from the same area as a previously sampled population (MA00). Samples of infected plants showing characteristic symptoms of leaf blight were collected from each field, from three to six infested foci (at least $10 \mathrm{~m}$ apart) in each distinct row, from a total of 10 to 15 rows per field. Isolations were made by transferring fragments of infected leaves to plates containing selective medium (33) and incubating at $25^{\circ} \mathrm{C}$ in the dark. Pure cultures of $R$. solani were established by transferring hyphal tips (following growth in the selective medium for 24 to $48 \mathrm{~h}$ ) to potato dextrose agar. Sclerotia from 5-day-old cultures from each isolate were transferred to $1.8-\mathrm{ml}$ cryotubes (Nunc CryoLine System, Denmark) containing anhydrous silica gel for long-term storage at $4{ }^{\circ} \mathrm{C}$, after 10 days incubation at $25^{\circ} \mathrm{C}$. The anastomosis group of the isolates was determined by selective amplification of part of the $28 \mathrm{~S}$ ribosomal DNA (rDNA) region of the fungus using the specific primers designed for $R$. solani AG-1 IA: $R$. solani AG-common primer (forward) 5'-CTCAAACAGGCATGCTC-3' and $R$. solani AG 1IA specific primer (reverse) 5'-CAGCAATAGTTGGTGGA-3' (42).

Data collection. DNA was extracted as described earlier (36). Ten polymorphic codominant microsatellite (SSR) loci (71) were used to genotype each isolate using fluorescent-labeled primers. Polymerase chain reactions (PCR) were carried out separately for each SSR locus in $20-\mu \mathrm{l}$ volumes containing $5 \mu \mathrm{l}$ of genomic DNA (5 to $15 \mathrm{ng}$ of final concentration), $2 \mu \mathrm{l}$ of $10 \times$ PCR buffer, $0.4 \mathrm{mM}$ dNTP, $0.3 \mu \mathrm{M}$ of each primer and 1 unit of Taq polymerase. PCR comprised initial denaturation of $2 \mathrm{~min}$ at $96^{\circ} \mathrm{C}$, followed by 35 cycles of denaturation for $30 \mathrm{~s}$ at $96^{\circ} \mathrm{C}$, annealing for $30 \mathrm{~s}$ at $50^{\circ} \mathrm{C}$ and elongation for $30 \mathrm{~s}$ at $72^{\circ} \mathrm{C}$, with a final extension step of $5 \mathrm{~min}$ at $72^{\circ} \mathrm{C}$. Since we were not able to obtain a PCR amplicon from all of the soybean isolates using the primer set already described (71) for locus Tc10, a new pair of primers was designed for this locus as follows: Tc10newF2 (5'-GGTTCTTCGAAAAGATCAAGTAAGC-3') labeled with 6-FAM dye and Tc10newR2 (5'-TTGCTGGGGTTGTTGAGGTT-3') unlabeled. Amplicons were separated on an ABI 3700 sequencer using GeneScan 500 LIZ as size standard (both from Applied Biosystems, Foster City, CA) according to the manufacturer's instructions, and the allele fragment analyses were performed with the programs GENESCAN and GENOTYPER version 3.7 supplied by ABI. A control isolate (TC06BRZ_MT_S024, with the multilocus microsatellite genotype MLMG 42) was included in every run of 95 samples. Further evidence for reproducibility of the molecular markers was obtained by comparing sizes of each allele at every locus for 14 isolates randomly selected from all five populations (TC98BRZ_S028, and S076, TC00BRZ_S123, TC05BRZ_MA183, MA220, MA235, MA242, MA260, MTS023, MTS079, MTS132, TO136, TO034, and TO025). The data from this independent genotyping was used to describe the microsatellite genotyping system (71). The statistical binning of the alleles into fragment size categories (consistent with the repeat unit increments described in (71) was implemented using the program FLEXIBIN (Department of Zoology, Cambridge University, UK).

Microsatellite information content. In all analyses we assumed that $R$. solani AG-1 IA is a functional diploid (i.e., it is a dikaryon). All of our data were consistent with this assumption. The variation in allele size, the range in number of repeats, the total and the average number of alleles per locus, and the identification of private alleles (i.e., those present in only one population) were determined using information on allele frequencies computed by the program CONVERT version 1.31 (Purdue

TABLE 1. Populations of the soybean-infecting fungus Rhizoctonia solani anastomosis group-1 IA used in this study

\begin{tabular}{|c|c|c|c|c|c|c|c|}
\hline State & County & Population & $N$ & Geographical coordinates & Cultivar & $\begin{array}{l}\text { Sampling } \\
\text { year }\end{array}$ & Collector \\
\hline \multirow[t]{2}{*}{ Mato Grosso } & $\begin{array}{l}\text { Lucas do Rio } \\
\text { Verde }\end{array}$ & MT98 & 54 & $-55.93 \mathrm{~W}-16.33 \mathrm{~S}$ & FT-108 & 1998 & $\begin{array}{l}\text { R. C. Fenille, Ministry of Agriculture, Goiânia, } \\
\text { Goiás, Brazil }\end{array}$ \\
\hline & Sorriso & MT06 & 55 & $-55.75 \mathrm{~W}-12.60 \mathrm{~S}$ & Perdiz & 2006 & M. B. Ciampi, UNESP, São Paulo, Brazil \\
\hline \multirow[t]{2}{*}{ Maranhão } & Balsas & MA00 & 10 & $-46.05 \mathrm{~W}-7.52 \mathrm{~S}$ & Sambaiba & 2000 & M. C. Meyer, EMBRAPA, Balsas, Maranhão, Brazil \\
\hline & Balsas & MA06 & 91 & $-47.05 \mathrm{~W}-6.52 \mathrm{~S}$ & Msoy 8925 & 2006 & M. C. Meyer \\
\hline Tocantins & Tupirama & TO06 & 22 & $-48.17 \mathrm{~W}-8.97 \mathrm{~S}$ & Candeia & 2006 & M. C. Meyer \\
\hline
\end{tabular}


University, West Lafayette, IN). The complete allele frequency distributions of the 10 microsatellite loci in five soybean-infecting populations of Rhizoctonia solani AG-1 IA from Brazil are available in supplementary files.

Clonal diversity. A multilocus genotype for each fungal strain was determined using the program GENOTYPE (Institute for Biodiversity and Ecosystem Dynamics, Universiteit van Amsterdam, Netherlands; [46]). Isolates with the same multilocus SSR genotype were treated as clones. Several indices of clonal diversity were determined, including: (i) the number of genotypes per population; (ii) site specific genotypes; (iii) the clonal fraction (or the proportion of fungal isolates originating from asexual reproduction), calculated as 1 - ([number of different genotypes]/[total number of isolates]) (72); (iv) both the Stoddart and Taylor's genotypic diversity $G_{0}=1 / \Sigma p_{i}^{2}$, where $p_{i}$ is the frequency of the $i$ th genotype (61), and its evenness ( $G_{0}$ scaled by the maximum number of expected genotypes; [26]), an indicator for how evenly the genotypes are distributed over the population. These measures were calculated using the program GENODIVE (Institute for Biodiversity and Ecosystem Dynamics, Universiteit van Amsterdam [46]). To test whether pairs of populations differed in their genotype diversity, we used a bootstrapping approach (resampling with replacement), where the individuals were resampled from the populations and the diversity indices were compared after every replicate (40) using 1,000 permutations with subsampling to match the size of the smallest population (26). The complete multilocus microsatellite genotype data are available in a supplementary file.

Gene diversity and population differentiation. Nei's unbiased gene diversity was estimated as $n /(n-1) \times\left(1-\sum_{i} p_{i}^{2}\right)$, where $p$ is the observed frequency of the $i$ th allele (52). Allelic richness was estimated as the mean number of alleles per locus (16) for a standardized sample size of 10, using rarefaction (29) as described by Petit et al. (53). To test whether groups of samples differed for allelic richness and gene diversity, we used FSTAT version 2.9.3.2 (Department of Ecology and Evolution, Lausanne, Switzerland). $P$ values for testing the significance of the pairwise comparisons were obtained after 1,000 permutations.

Spatial analysis of molecular variance (SAMOVA) was used to define groups of populations that were geographically homogeneous and maximally differentiated from each other. This approach can be applied to both genotypic and haplotypic data and it makes no assumptions about Hardy-Weinberg equilibrium within populations or about the linkage equilibrium between loci (15). The method uses a simulated annealing procedure to divide the $n$ sampled populations into $K$ groups ( $K$ is here assumed to be known), in order to find the composition of the $K$ groups and to maximize the proportion of total genetic variance due to differences between groups of populations (19). We performed this analysis using the program SAMOVA version 1.0 (University of Bern, Switzerland).

After defining the $K$ groups, the distribution of gene diversity was evaluated based on hierarchical analysis of molecular variance (AMOVA). We calculated fixation indices ( $F$ statistics) with the purpose of quantifying differentiation between pairs of populations and to assess the degree of population subdivision, based on the sum of squared size differences for microsatellite loci $\left(R_{\mathrm{ST}}\right)$ (60). The null distribution of pairwise $F$ statistics values under the hypothesis of no differentiation between two populations was obtained by permutating haplotypes between populations. Genetic differentiation between populations was considered significant when $P$ was less than the 5\% nominal level. The AMOVA was conducted to partition the covariance components due to amonggroups effect, among-populations-within-group effect, and within-population effect. Significance of the fixation indexes was tested using 1,023 permutations by a nonparametric approach (19) using the program ARLEQUIN version 3.11 (Zoological Institute, Department of Biology, University of Bern, Switzerland).
Hardy-Weinberg and gametic equilibrium tests. To assess the contribution of recombination to the genetic structure of $R$. solani AG-1 IA populations, we investigated the associations within and among loci through tests for Hardy-Weinberg equilibrium (HWE) and multilocus association, respectively. Tests for HWE for each locus within each population used an HWE test analogous to Fisher's exact test (27). $P$ values were obtained using a Markov chain Monte Carlo (MCMC) approach, generating an exact probability distribution not biased by rare alleles or low sample size (56), implemented in ARLEQUIN 3.11. We also calculated the inbreeding coefficient $\left(F_{\text {IS }}\right)$ across loci following Weir and Cockerham (65) to test for a significant deficit or excess of heterozygotes (when compared with HWE expectations), based on 1,000 permutations and implemented in ARLEQUIN 3.11. The associations among loci were tested using Fisher's exact test (24) based on an MCMC algorithm (with 1,000 batches and 1,000 iterations/batch). This test was implemented by GENEPOP version 3.4 (Institut des Sciences de l'Evolution, Université Montpellier 2, Montpellier, France). Two loci were considered in gametic disequilibrium (GD) when their associated $P$ value was $\leq 0.05$. We also measured the index of association $\left(I_{\mathrm{A}}\right)(43)$, testing for significance with 1,000 randomizations, and an alternative measure of $I_{\mathrm{A}}, \bar{r}_{D}$, that is less sensitive to the number of loci (4). These tests were implemented using MULTILOCUS version 1.3 (Department of Biology, Imperial College, Silwood Park, UK), fixing missing data during randomizations.

Test for admixture or hidden population structure. Departures from HWE and gametic equilibrium observed in some populations of $R$. solani AG-1 IA could be caused by a Wahlund effect (i.e., population admixture). To determine whether any individuals in a sample were immigrants with respect to their reference geographical population, we used a Bayesian statistical model (55) implemented by STRUCTURE version 2.2 (Department of Human Genetics, University of Chicago, IL). This program calculates the membership coefficients to each of the populations $(\widehat{Q})$ of every multilocus genotype sampled (which were assigned a priori to their reference populations). We performed 10 runs with a burn-in period of 10,000 generations and MCMC simulations of 100,000 iterations each run.

Demographic parameters. Recent founder effects or historical bottlenecks were evaluated using the test developed by Cornuet and Luikart (12) and implemented in the program BOTTLENECK version 1.2 (Laboratoire de Modélisation et de Biologie Evolutive, INRA, Montpellier, France). This test uses a coalescent approach to check for heterozygosity excess or deficiency, based on the expected heterozygosity and the observed number of alleles at each individual locus (54). We used the strict stepwise mutation model (SMM). Significant heterozygote deficiency can be interpreted as a recent population expansion and an excess of heterozygotes is expected following a recent bottleneck. A neutral equilibrium model predicts an equal number of loci with heterozygote excess and deficiency for a population in which the effective size has remained fairly constant in the past. Deviations from mutation-drift equilibrium across all loci, for each population sample, were assessed for statistical significance using the sign test and Wilcoxon's rank test, because these tests are robust when using fewer than 20 polymorphic loci (12).

Historical migration and population size fluctuation. Historical migration between populations was estimated with MIGRATE version 2.3 (Department of Biological Science, Florida State University, Tallahassee, FL). MIGRATE is based on the coalescent theory and uses a maximum likelihood approach to estimate effective population sizes and a migration matrix. It allows for estimation of asymmetrical migration between population pairs (6). Initial estimates of gene flow among populations were obtained with MIGRATE 2.3 using five replicates of 10 initial chains and five long final chains, and a static heating scheme with four temperatures $(1.0,1.3,2.6$, and 3.9). The data 
type chosen was microsatellite data with Brownian motion, assuming the stepwise mutation model. The initial chains were performed with 1,000 samples and a sampling interval of 20 (20,000 steps), with 1,000 trees recorded per short sample. The five final chains were carried out with 5,000 samples and a sampling interval of 20 (200,000 steps), a burn-in of 10,000 , and 10,000 trees recorded per long chain. The confidence interval for theta and migration parameter $M$ was calculated using a percentile approach.

Population size fluctuation for each population were tested using an MCMC method implemented in LAMARC version 2.1 (Department of Genome Sciences, University of Washington, Seattle) using two replicates of 10 initial chains and two long final chains. The initial chains were performed with 2,500 samples and a sampling interval of 20 (50,000 steps), using a burn-in of 1,000 samples for each chain and 2,500 genealogies recorded per chain. The two final chains were carried out with 25,000 samples and a sampling interval of 20 (500,000 steps), burn-in of 10,000, and 25,000 trees recorded for each chain. The confidence interval for the exponential growth rate ' $g$ ' was calculated using the percentile approach. The ancestral $N_{e}$ at ' $t$ ' time ago was calculated using the following equation of population growth: $\theta_{t}=\theta_{\text {now }} e^{-g t}$, where ' $\theta$ ' is $4 N_{e} \mu$, ' $t$ ' is the time in mutational units, and ' $g$ ' is the exponential growth parameter $(34,35)$.

\section{RESULTS}

Gene and genotypic diversity. The 10 SSR loci had 4 to 13 alleles per locus (average of 7.4 alleles), with gene diversities per locus and across populations ranging from 0.39 to 0.74 . Private alleles were present in all populations. Measures of genotypic and gene diversity for the five populations are summarized in Table 2. Seventy-six different MLGTs were found among the 232 isolates analyzed. The clonal fraction ranged from zero in MA00 (where no clones were identified) to 0.84 in MA06. The mean genotypic diversity value, estimated using Stoddart and Taylor's measure, was 5.76. Only three haplotypes were shared among different populations, one between MT98 and MA06 and two between MT06 and TO06 (Table 2). We also performed a bootstrap test to compare differences in genotypic diversity among populations. The populations MA00 and TO06 had the highest genotypic diversity while MA06 had the lowest one (Table 2). The average allelic richness across all populations was 2.89 .

All 76 genotypes of $R$. solani AG-1 IA were heterozygous for at least one locus. The expected heterozygosity $\left(\mathrm{H}_{\mathrm{E}}=\right.$ Nei's unbiased gene diversity) varied from 0.43 to 0.60 across populations (Table 2). The populations from Mato Grosso (MT98 and MT06) had significantly higher $\mathrm{H}_{\mathrm{E}}$, while MA00 and MA06 had the lowest heterozygosity. The populations MT98 and MT06 also had significantly higher levels of allelic richness (3.3 and 3.4, respectively) while MA00 had the lowest one (2.2).

Hierarchical distribution of total gene diversity. We used SAMOVA to determine the best grouping of populations using both geographical information and allele frequency variation, assuming two to four groups $(K)$ and using the distance method based on the sum of squared size differences $\left(R_{\mathrm{ST}}\right)$. The best SAMOVA grouping (the one with the highest $\Phi_{\mathrm{CT}}$ and the lowest variation among populations within groups) was achieved by $K=$ 3. Based on $R_{\mathrm{ST}}$ and $K=3$ grouping, $82.6 \%$ of the total gene diversity was found within-populations, $5.1 \%$ existed among populations within groups and $12.3 \%$ was among groups (Table 3 ). This $K=3$ grouping was chosen for the subsequent analyses of population differentiation.

Population differentiation. Pairwise population differentiation was based on $F$-statistics using the sum of the squared number of repeat differences $\left(R_{\mathrm{ST}}\right)$, under SMM (Table 4$)$. The overall $R_{\mathrm{ST}}$ value was $0.17(P \leq 0.001)$, indicating an intermediate level of differentiation among geographically distinct populations (Table 3). Two cases of no significant differentiation were detected: between populations TO06 and MT98 $\left(R_{\mathrm{ST}}=0.013, P=0.38\right)$ and between TO06 and MT06 $\left(R_{\mathrm{ST}}=0.004, P=0.42\right)$. The highest $R_{\mathrm{ST}}$ value was found between MA00 and TO06 $\left(R_{\mathrm{ST}}=0.37, P \leq 0.01\right)$.

TABLE 2. Measures of genotypic and gene diversity in populations of Rhizoctonia solani anastomosis group-1 IA infecting soybean in Brazil

\begin{tabular}{|c|c|c|c|c|c|c|c|c|}
\hline Population & $\begin{array}{l}\text { Sample } \\
\text { size }(N)\end{array}$ & $\begin{array}{l}\text { Number of } \\
\text { genotypes }\end{array}$ & $\begin{array}{l}\text { Site-specific } \\
\text { genotypes }^{t}\end{array}$ & $\begin{array}{l}\text { Clonal } \\
\text { fraction }\end{array}$ & $\begin{array}{c}\text { Stoddart and Taylor's } \\
\text { genotypic diversity }\left(G_{\mathrm{O}}\right)^{\mathrm{uv}}\end{array}$ & Evenness $^{\mathrm{vw}}$ & $\begin{array}{l}\mathrm{H}_{\mathrm{E}}^{\mathrm{xy}} \text { (Nei's unbiased } \\
\text { gene diversity) }\end{array}$ & Allelic richness ${ }^{\mathrm{yz}}$ \\
\hline MA00 & 10 & 10 & $10(0)$ & 0.00 & $10.00 \mathrm{a}$ & $1.00 \mathrm{a}$ & $0.43 \mathrm{~b}$ & $2.23 \mathrm{~b}$ \\
\hline TO06 & 22 & 16 & $14(2)$ & 0.27 & $10.52 \mathrm{a}$ & $0.66 \mathrm{~b}$ & $0.56 \mathrm{ab}$ & $2.93 \mathrm{ab}$ \\
\hline MT06 & 55 & 22 & $20(2)$ & 0.60 & $3.54 \mathrm{~b}$ & $0.19 \mathrm{c}$ & $0.60 \mathrm{a}$ & $3.38 \mathrm{a}$ \\
\hline МТ98 & 54 & 16 & $15(1)$ & 0.70 & $3.05 \mathrm{bc}$ & $0.19 \mathrm{c}$ & $0.60 \mathrm{a}$ & $3.30 \mathrm{a}$ \\
\hline MA06 & 91 & 15 & $14(1)$ & 0.84 & $1.87 \mathrm{c}$ & $0.13 \mathrm{c}$ & $0.49 \mathrm{~b}$ & $2.62 \mathrm{ab}$ \\
\hline Overall & 232 & 79 & 73 & 0.69 & 5.76 & 0.43 & 0.54 & 2.89 \\
\hline
\end{tabular}

${ }^{t}$ Number of genotypes shared with other populations is shown in brackets.

u Stoddart and Taylor's genotypic diversity (61).

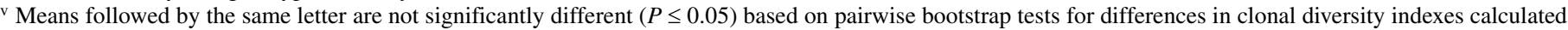

by GENODIVE (46), based on 1,000 permutations with subsampling to match the size of the smallest population.

${ }^{\text {w }} G_{0}$ scaled by the maximum number of expected genotypes; an evenness value $=1.0$ indicates that all genotypes have equal frequencies (26).

x Nei's unbiased gene diversity, also known as expected heterozygosity, averaged over all loci, corrected for the sample size (52).

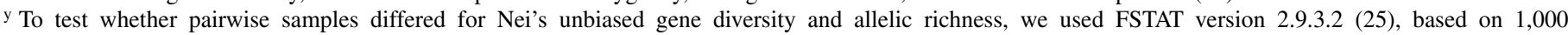
permutations; means followed by the same letter are not significantly different $(P \leq 0.05)$.

${ }^{\text {z }}$ Calculated according to El Mousadik and Petit (16).

TABLE 3. Hierarchical distribution of gene diversity among populations of Rhizoctonia solani anastomosis group-1 IA from soybean in Brazil

\begin{tabular}{|c|c|c|c|c|c|c|}
\hline \multirow[b]{2}{*}{ Source of variation } & \multirow[b]{2}{*}{ df } & \multicolumn{5}{|c|}{ Distance method: sum of squared size differences $\left(R_{\mathrm{ST}}\right)$} \\
\hline & & Sum of squares & $\begin{array}{c}\text { Variance } \\
\text { components }\end{array}$ & $\begin{array}{l}\text { Percentage of } \\
\text { variation }\end{array}$ & $\begin{array}{l}\text { Fixation } \\
\text { indices }\end{array}$ & $P$ \\
\hline Among groups ${ }^{\mathrm{Z}}$ & 2 & 602.8 & 5.4019 & 12.30 & $\Phi_{\mathrm{CT}}=0.1230$ & 0.09 \\
\hline Among populations within groups & 2 & 232.1 & 2.2439 & 5.11 & $\Phi_{\mathrm{ST}}=0.1740$ & $\leq 0.001$ \\
\hline Within populations & 153 & $5,551.6$ & 36.2849 & 82.60 & & \\
\hline Total & 157 & $6,386.5$ & 43.9308 & & & \\
\hline
\end{tabular}

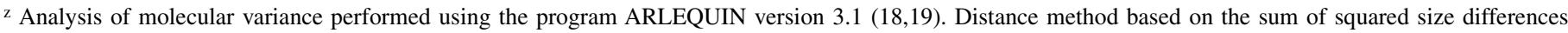
$\left(R_{\mathrm{ST}}\right)$ between two haplotypes, for microsatellite data (according to Slatkin [60]); number of permutations = 1,023; grouping proposed by SAMOVA based on $R_{\mathrm{ST}}(K=3)$ : MA00, (MT98, MT06, and TO06), and MA06. 
HWE equilibrium and gametic disequilibrium. Clone-corrected data were tested for HWE and for disequilibrium between pairs of loci (Table 5). Only population MA00 was in HWE for each of the nine polymorphic loci examined. We detected significant departures from HWE at three of nine loci for the population MA06, 5 of 10 loci for MT06 and TO06, and six of ten loci for the population MT98. The overall $F_{\text {IS }}$ was $0.15(P \leq 0.01)$. Significant positive $F_{\text {IS }}$ inbreeding coefficients (varying from 0.22 to $0.33, P \leq 0.02$ ) were observed for both populations from Mato Grosso, while negative $F_{\text {IS }}$ values were observed for MA00 and TO06 (Table 5).

The exact test for gametic disequilibrium was significant for most pairs of loci in all populations, except for TO06, in which only $13 \%$ of loci deviated significantly from equilibrium. All populations had significant indices of association, $I_{\mathrm{A}}$ or $\operatorname{rbarD}$ (Table 5). One locus pair was consistently associated across most of the populations (data not shown). To account for the possibility that linkage between these two loci may have influenced the estimates of disequilibrium, these loci ( $\mathrm{Tc01}$ and $\mathrm{Tc02}$ ) were removed and the data were re-analyzed. Gametic disequilibrium fell in populations MA00 (from 55.6 to 5.0\% of the locus-pairs) and TO06 (from 13.3 to $3.6 \%$ ) and $I_{\mathrm{A}}$ values became nonsignificant. The remaining three populations still exhibited significant gametic disequilibrium and $I_{\mathrm{A}}$ values remained significant $(P \leq 0.05)$.

Admixture. To determine if departures from HW expectations and gametic equilibrium reflected a hidden structure within any of the populations, we conducted a test for admixture implemented by the program STRUCTURE (55). We identified 10 likely admixed genotypes: six in the population MT98 (37.5\% of the total genotypes) and 4 in the population T006 (25\% of the total) (Fig. 1). In population MT98, genotypes 26 (BRS131), 27 (BRS134), and 28 (BRS136) showed significant membership coefficients not related to their original geographical population, suggesting that they could be immigrants from population TO06, while genotypes 30 (BRS14), 31 (BRS15), and 35 (BRS29) were probable immigrants from population MA00 (Fig. 1). In population TO06, there were two probable immigrant genotypes (64 [BRZTO006] and 66 [BRZTO003]) that could have originated from the population MA06, one (67 [BRZTO022]) from the population MA00, and one (65 [BRZ TO136]) that could have originated either from MA06 or from MT06. Removing the admixed genotypes from populations MT98 and TO06 increased the proportion of loci showing HWE in both populations (Table 5). Indices of gametic equilibrium $\left(I_{\mathrm{A}}\right.$ or $\left.\bar{r}_{D}\right)$ for individual populations also decreased to nonsignificant values and there was a reduction in the proportion of locus pairs in disequilibrium.

Demographic parameters. We employed Cornuet and Luikart's test (12) to detect heterozygosity deficiency or excess and determine if allele distributions within populations had been perturbed by changes in population size. Under the expectations of the stepwise mutation model (SMM), no indication of recent bottlenecks was found in any population (Table 6).

Historical migration and population size fluctuation estimates. The population parameter theta $(\Theta)$ was used as a relative measure of effective population size (Fig. 2). The population size estimates were very similar $(\Theta=0.82$ to 1.06$)$. Estimates of directional gene flow indicated historical migration among the different populations. The population that donated the highest number of migrants to most of the populations (with the exception of MA00) was TO06 (migration rates $4 \mathrm{Nm}_{\mathrm{TO} 06 \rightarrow \mathrm{MT} 06}=1.71$, $4 N m_{\mathrm{TO} 06 \rightarrow \mathrm{MA} 06}=1.65$, and $\left.4 N m_{\mathrm{TO} 06 \rightarrow \mathrm{MT} 98}=0.97\right)$. A much smaller historical movement of migrants was indicated in the opposite direction towards TO06. The other high asymmetric migration esti-

TABLE 4. Measures of population differentiation among populations of Rhizoctonia solani anastomosis group-1 IA from soybean in Brazil based on $R_{\mathrm{ST}} \mathrm{y}^{\mathrm{y}}$

\begin{tabular}{|c|c|c|c|c|c|}
\hline Populations & MA00 & МТ98 & MA06 & MT06 & TO06 \\
\hline MA00 & - & & & & \\
\hline МТ98 & 0.2414 & - & & & \\
\hline MA06 & 0.1979 & 0.1495 & - & & \\
\hline MT06 & 0.2399 & 0.1092 & 0.0806 & - & \\
\hline TO06 & 0.3692 & $0.0131^{\mathrm{z}}$ & 0.1282 & $0.0041^{\mathrm{z}}$ & - \\
\hline
\end{tabular}

y Distances computed as sum of squared size differences between two haplotypes, according to Slatkin (60).

${ }^{\mathrm{z}}$ Nonsignificant values $(P \geq 0.05)$ based on 1,023 permutations.

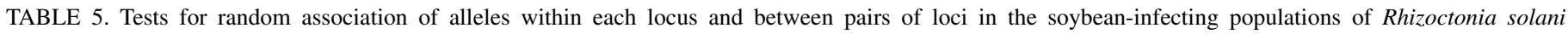
anastomosis group-1 IA from Brazil

\begin{tabular}{|c|c|c|c|c|c|c|c|c|c|c|}
\hline \multirow[b]{2}{*}{ Origin } & \multirow[b]{2}{*}{ Population } & \multirow[b]{2}{*}{ Admixed genotypes ${ }^{s}$} & \multirow[b]{2}{*}{$\begin{array}{l}\text { Number of } \\
\text { loci in } \mathrm{HWE}^{\mathrm{t}}\end{array}$} & \multirow[b]{2}{*}{$\begin{array}{l}\text { Population- } \\
\text { specific } F_{\text {IS }}{ }^{\mathrm{u}}\end{array}$} & \multirow[b]{2}{*}{$P$} & \multicolumn{5}{|c|}{ Gametic equilibrium estimates } \\
\hline & & & & & & $I_{\mathrm{A}}^{\mathrm{vx}}$ & $\operatorname{rbarD}^{\mathrm{wx}}$ & $P^{\mathrm{x}}$ & $\begin{array}{l}\text { Locus pairs at signifi- } \\
\text { cant disequilibrium }\end{array}$ & $\%^{\mathrm{y}}$ \\
\hline \multirow[t]{2}{*}{ Maranhão } & MA00 & No admixture detected & 9 in $9^{z}$ & -0.28 & 0.91 & 0.9676 & 0.0551 & 0.001 & 20 in 36 & 55.6 \\
\hline & MA06 & No admixture detected & 6 in $9^{z}$ & 0.27 & 0.06 & 1.6051 & 0.1567 & $<0.001$ & 18 in 36 & 50.0 \\
\hline \multirow[t]{3}{*}{ Mato Grosso } & МТ98 & $6 / 16(=37.5 \%)$ & 4 in 10 & 0.33 & 0.003 & 1.1200 & 0.1168 & $<0.001$ & 23 in 45 & 48.9 \\
\hline & $\begin{array}{l}\text { MT98 with } \\
\text { no admixture }\end{array}$ & & 6 in 10 & 0.17 & 0.11 & $0.4560^{\mathrm{NS}}$ & $0.0600^{\mathrm{NS}}$ & 0.144 & 2 in 36 & 5.6 \\
\hline & MT06 & No admixture detected & 5 in 10 & 0.22 & 0.02 & 0.6622 & 0.0461 & $<0.001$ & 23 in 36 & 51.1 \\
\hline \multirow[t]{2}{*}{ Tocantins } & TO06 & $4 / 16(=25.0 \%)$ & 5 in 10 & -0.33 & 0.99 & 0.3771 & -0.0111 & 0.032 & 6 in 45 & 13.3 \\
\hline & $\begin{array}{l}\text { TO06 with } \\
\text { no admixture }\end{array}$ & & 6 in 10 & -0.38 & 0.99 & $0.1278^{\mathrm{NS}}$ & $0.0152^{\mathrm{NS}}$ & 0.457 & 2 in 45 & 4.4 \\
\hline
\end{tabular}

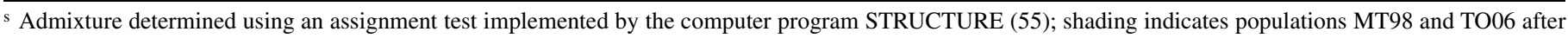
removal of admixed genotypes.

${ }^{t}$ Hardy-Weinberg equilibrium (HWE) test performed according to an exact test analogous to the Fisher exact test (27).

u Population-specific $F_{\text {IS }}$ indices (based on 1,023 permutations).

${ }^{v} I_{\mathrm{A}}$ and $\mathrm{rBarD}$ are indices of multilocus gametic disequilibrium (43).

${ }^{\mathrm{w}}$ The $\mathrm{rBarD}$ is a modification of $I_{\mathrm{A}}$ which removes the dependency on number of loci (4).

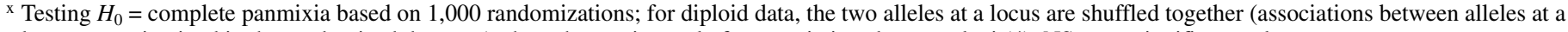

locus are maintained in the randomized data sets); thus, the test is purely for associations between loci (4). NS = nonsignificant values.

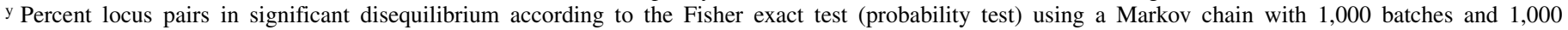
iterations/batch, implemented by GENEPOP 3.4 (56).

z One monomorphic locus.
} 
mates were observed between MT98 and MT06 $\left(4 N m_{\mathrm{MT} 98 \rightarrow \mathrm{MT} 06}=\right.$ $\left.1.49 ; 4 N m_{\mathrm{MT} 06 \rightarrow \mathrm{MT} 98}=1.09\right)$. In general, the two populations from Mato Grosso (MT98 and MT06) contributed the smallest number of migrants to the other populations. There was no evidence for population expansion. All the populations showed either zero (MA00) or slightly negative growth rate estimates (Fig. 2).

\section{DISCUSSION}

This study represents the first in-depth population genetic analysis of the soybean-infecting foliar blight pathogen $R$. solani AG-1 IA from Brazil. Our sampling strategy covered the most important soybean cropping areas in central-western and northern Brazil. We tested the hypotheses that geographical populations of $R$. solani AG-1 IA from soybean are genetically homogeneous (hence not subdivided or differentiated) and that these populations are recombining in structure.

Gene flow was only detected between populations TO06 and MT06, and between TO06 and MT98 (Table 4). The presence of private alleles in all populations and very few shared multi- locus genotypes (3 out of 76) provided additional evidence for limited dispersal between geographically distant regions, supporting the alternative hypothesis of restricted gene flow among populations. Geographic isolation is the most likely cause of this genetic differentiation. In most cases, sites were more than $1,000 \mathrm{~km}$ apart.

There were three cases of the same genotype shared among soybean fields. Genotypes 61 and 62 were shared between MT06 and TO06 (which were separated by $1,000 \mathrm{~km}$ ) and genotype 20 was found in both MT98 and MA00 (1,400 km apart). Based on allele frequencies at each locus, we calculated the probability of unrelated isolates sharing the same multilocus genotype (64). Since these probabilities were very low, ranging from $10^{-7}$ to $10^{-4}$, we do not believe that these genotypes were shared by chance. Rather we believe that these shared genotypes are due to movement of infested seeds over long distances $(36,39)$. Although soybean growers in central-western and Northern Brazil could produce their own seeds locally, many obtain their seeds from a few centralized seed distributors $(17,58)$. This would facilitate the spread of seedborne pathogens such as $R$. solani AG-1 IA and the
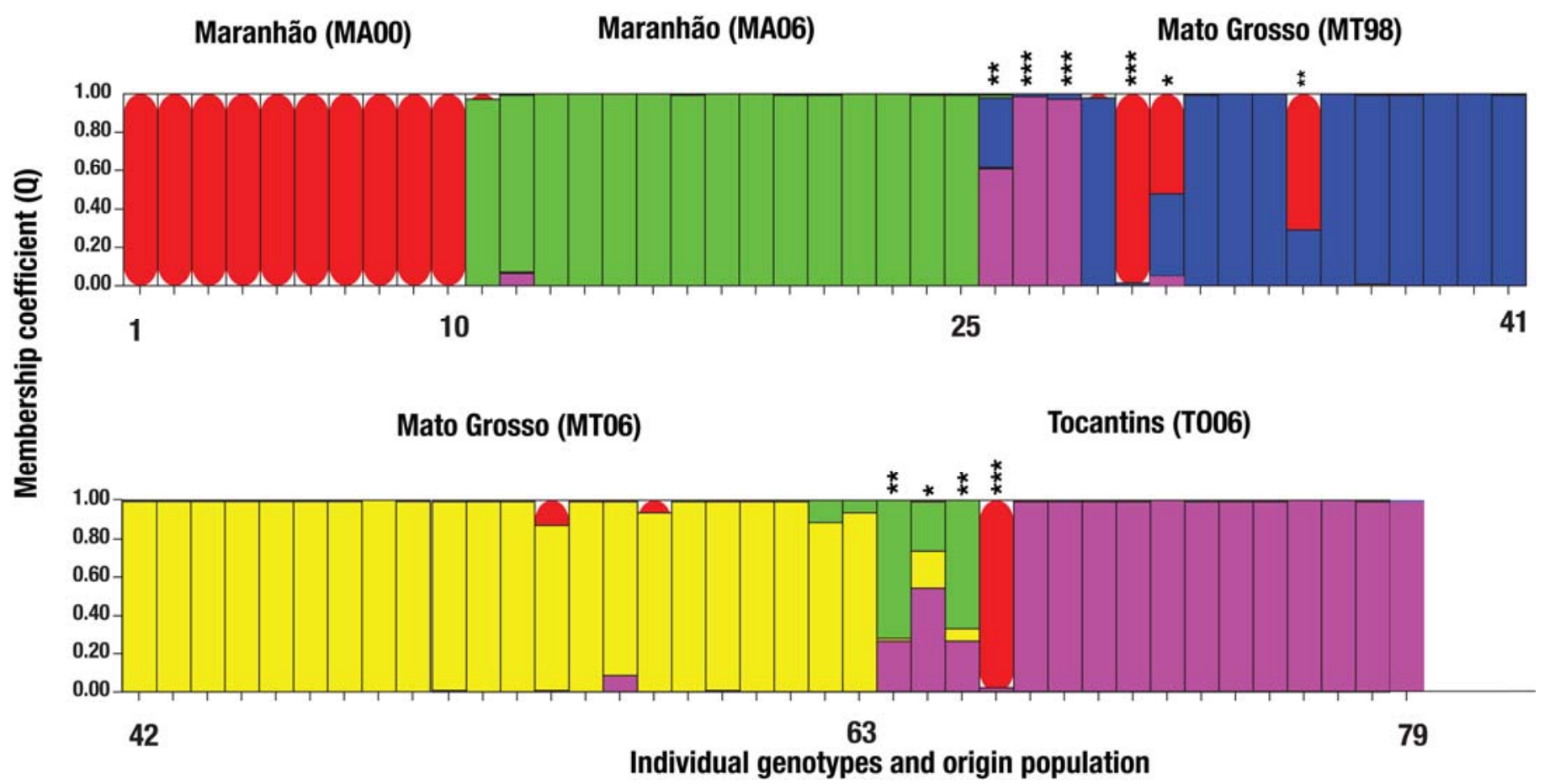

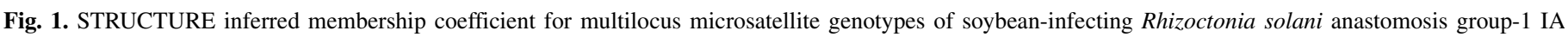

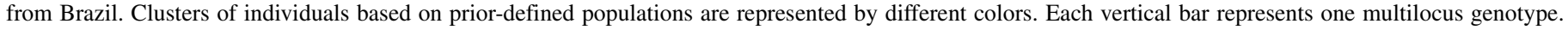

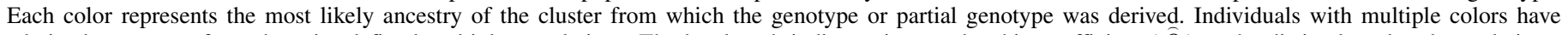

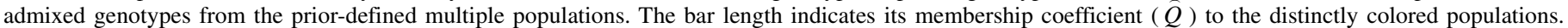
Statistically significant admixture for an individual multilocus genotype is noted with an asterisk along the top.

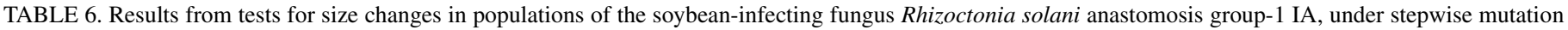
model of evolution

\begin{tabular}{|c|c|c|c|c|c|}
\hline \multirow[b]{2}{*}{ Population } & \multirow[b]{2}{*}{$\mathrm{HD} / \mathrm{HE}^{\mathrm{x}}$} & \multirow[b]{2}{*}{ Exp. H exc. ${ }^{y}$} & \multicolumn{2}{|r|}{ Probabilityz $^{\mathrm{z}}$} & \multirow[b]{2}{*}{ Interpretation } \\
\hline & & & Sign test & Two-tailed Wilcoxon's test for overall H excess or deficiency & \\
\hline MA00 & $3 / 6$ & 5.02 & 0.38 & 0.36 & No deviation \\
\hline MA06 & $3 / 6$ & 5.13 & 0.41 & 0.25 & No deviation \\
\hline MT98 & $6 / 4$ & 5.85 & 0.19 & 0.28 & No deviation \\
\hline MT06 & $7 / 3$ & 5.86 & 0.07 & 0.23 & No deviation \\
\hline TO06 & $3 / 7$ & 5.93 & 0.37 & 0.43 & No deviation \\
\hline
\end{tabular}

${ }^{x} \mathrm{HD}=$ observed number of loci with heterozygosity deficiency; HE = observed number of loci exhibiting heterozygosity excess.

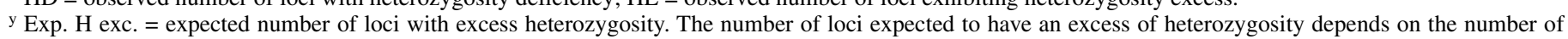
chromosomes sampled, the number of alleles observed, and the heterozygosity expected from the observed allele frequencies under the assumption that the populations are at mutation-drift equilibrium and that all loci mutate according to the model specified.

${ }^{\mathrm{z}}$ Probabilities from the two tests (sign test and Wilcoxon signed rank test) were calculated using the BOTTLENECK program (12,38,54). 
dispersal of fungal genotypes across distant geographical areas. If seedborne inoculum is shown to play a significant role in long distance dispersal, improved seed testing and seed treatment may be required, and control measures (e.g., seed treatment with eradicant fungicides) can be specifically targeted at seed. Sharing of planting and harvesting equipment among distant soybean growing regions is unusual in Brazil (17), hence their role in pathogen dispersal is likely to be limited.

The analysis with MIGRATE indicated asymmetrical historical migration in most pairwise population comparisons (Fig. 2), which might explain the current levels of subdivision. The only exception was between TO06 and both populations from Mato Grosso, which exhibited high current gene flow despite the historical asymmetric migration. The evidence for high asymmetric historical migration originating from TO06 suggests that it could be the founder population that contributed most of the immigrants, perhaps through movement of infested seed. Historically, with a northwards expansion towards the Cerrado, the soybean cropping reached Mato Grosso first (in the late 1980s) and only later Tocantins and Maranhao (in the mid 1990s), displacing traditional rice cropping areas (20). However, rice, which is another important host for $R$. solani AG-1 IA, has been a traditional crop in Tocantins for more than 50 years (30). In fact, the first report of the Rhizoctonia foliar and sheath blight diseases on both soybean and rice was from Goias, in 1985 (8). The northern part of Goias is in the current Tocantins State.

In contrast to what is known for other $A G$ groups, almost no information is available on the ecological and epidemiological importance of the sexual cycle for $R$. solani AG-1 IA (50). Several AGs in the $R$. solani complex possess either homothallic (selffertile) or bipolar, heterothallic mating systems (14). At least two AGs (AG-1 IC and AG-4) have heterothallic, bipolar mating systems, which is controlled by a single gene with multiple alleles (1). Several others AGs with heterothallic mating systems can also exhibit homothallic behavior, through a process of homokaryotic fruiting (3). There is no information about the mating system of AG-1 IA, i.e., whether the fungus is homothallic or heterothallic. $R$. solani AG-1 IA is thought to have a predominantly sexual reproductive system on soybean because sexual fruiting structures (hymenia and basidiospores) have been observed in soybean fields (31). Population genetic evidence from two studies of rice-infecting populations in the United States (57) and India $(36,62)$ indicated sexual reproduction and a recombining structure for $R$. solani AG-1 IA on rice. Our expectation was that the soybean-infecting fungus would also be sexually recombining in Brazil. The predictions for a sexually recombining

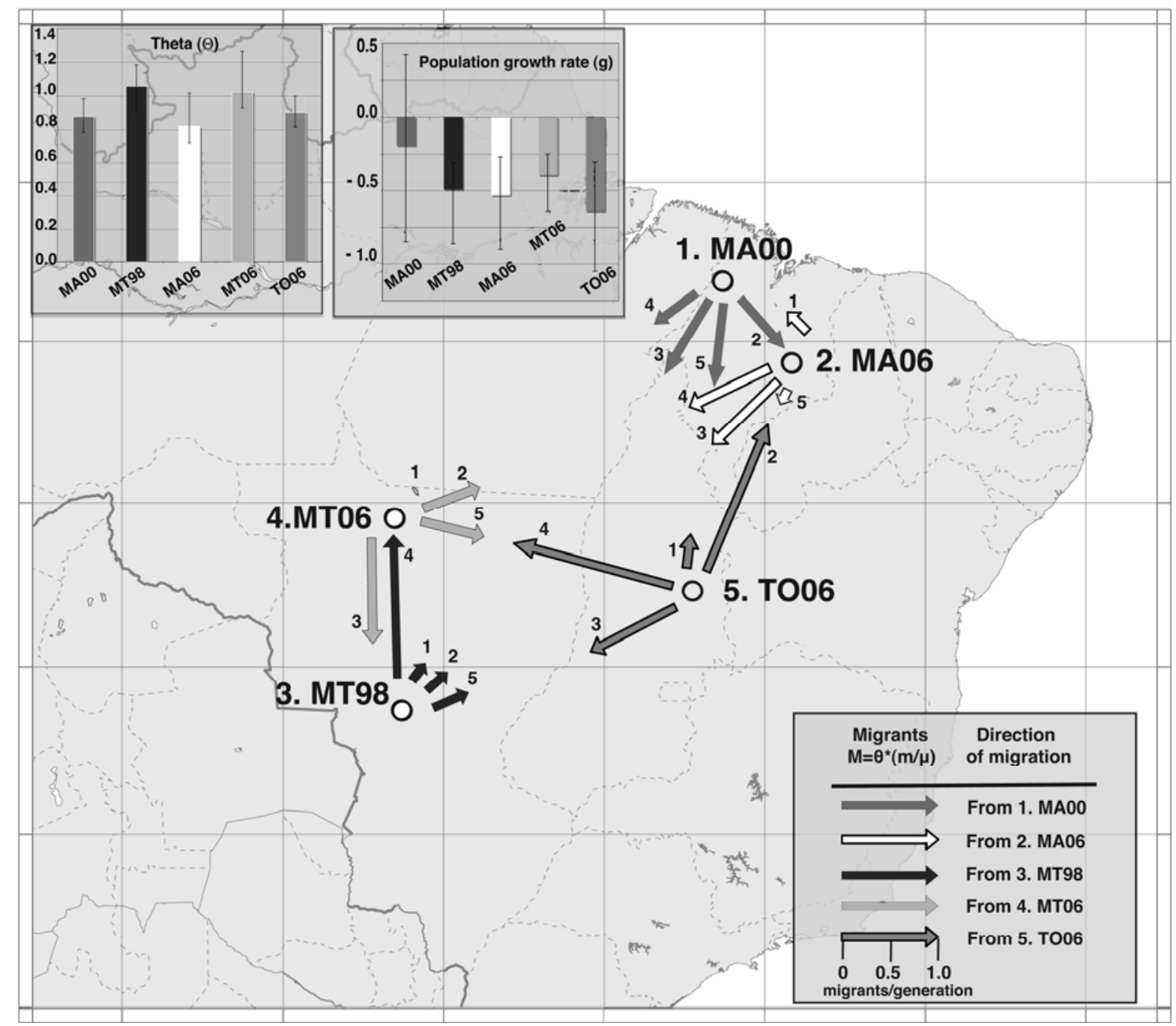

Fig. 2. Estimates of demographic parameters from the divergence among soybean-infecting populations of Rhizoctonia solani anastomosis group-1 IA from Brazil based on variation in 10 microsatellite loci. Theta values represent a measure of effective population size (for diploids theta $=4 N \mathrm{e} \mu$ where $N \mathrm{e}=$ effective population size and $\mu=$ mutation rate inferred for each locus). Migration between geographical populations was estimated using an isolation with migration model. Both theta values and migration rates were estimated using MIGRATE 2.3 (6). The directions for migration between sink and source populations are indicated by arrows. Most probable estimates of the exponential population growth rate $(g)$ were calculated by Bayesian analyses using the program LAMARC 2.0 $(34,35)$. Estimates of population growth and theta include $95 \%$ confidence intervals indicated as vertical bars. 
heterothallic organism are high genotypic diversity, low clonality, neutral markers at HWE proportions, and gametic equilibrium $(44,49)$.

The majority of the populations had intermediate to high genotypic diversity (Table 2). However, for some populations, the levels of genotypic diversity were very low and the associated clonal fraction very high. The highest clonal fraction observed was $84 \%$ in the population MA06 (Table 2). The exact test of HWE revealed significant deviations in most of the soybean-infecting populations, except for population MA00. In this population, all the loci conformed to HWE expectations, consistent with sexual reproduction (Table 5). Gametic disequilibrium was high in all of the populations except for TO06 (Table 5). Gametic disequilibrium can be generated by several processes, including linkage, population admixture, genetic drift, population expansion, nonrandom mating, and selection (49).

After removing a possibly linked locus pair (Tc01 and Tc02), gametic disequilibrium fell in populations MA00 and TO06. The remaining three populations still exhibited significant disequilibrium. Removing the admixed genotypes from TO06 and MT98 increased the proportion of loci under HWE expectations and restored gametic equilibrium (as measured by $I_{\mathrm{A}}$ or $\bar{r}_{D}$ ). Our interpretation is that linkage may have contributed to, but was not the sole explanation for the observed disequilibrium.

The occurrence of recent bottlenecks is an alternative explanation for the departures from HWE and for the observed gametic disequilibrium. A reduction in allelic richness is an indication that populations have experienced a recent reduction in their effective population size (54). However, we detected no significant deviations from mutation-drift equilibrium in these soybean-infecting populations. Allelic richness values were similar across all populations of the fungus, suggesting no particular lower trend (Table 2 ), and no excess heterozygosity (which is expected after a recent bottleneck) was observed (Table 6). We conclude that bottlenecks did not cause the observed disequilibrium.

Population expansion is another plausible explanation for gametic disequilibrium. From 1970 to 2001 soybean production in Brazil has expanded towards more foliar blight-conducive areas in the Amazonian biome at $27.5 \mathrm{~km}$ northwards per year (59). The higher temperatures and moist conditions predominant in northern Brazil are favorable to abundant hymenia formation and basidiospore germination $(5,51)$. In response to the enormous expansion of the soybean cropping areas, which had reached about 20.6 million hectares by 2007 (11), the effective population size of the fungus could also have become much larger. Large populations could maintain genetic diversity generated by previously recombinant ancestors, even if recombination occurs only rarely, with drift acting only weakly to reduce genetic variation $(7,28)$. However, there was no evidence for recent population expansion (Fig. 2 ), leading to the interpretation that an increase in population size was not the cause of the observed disequilibrium. To the contrary, all the populations showed either zero (MA00) or slightly negative growth rate estimates (Fig. 2).

The last plausible causes of gametic disequilibrium are excess outcrossing (disassortative mating) and excess inbreeding (assortative mating). We found evidence for assortative mating in $R$. solani AG-1 IA from soybean in Brazil. $F_{\text {IS }}$ was significant and positive for MT98 and MT06, and very close to significance in MA06 (Table 5), which is consistent with an excess of homozygosity expected under inbreeding. Previous studies showed that some $R$. solani AGs have a bipolar heterothallic mating system, such as AG-1 IC (32), AG-2-2 IV (63), AG-4 (13), and AG-8 (68), while AG-3 might be homothallic on tobacco $(1,9)$. Though the data from this survey cannot be considered conclusive, our findings are consistent with a significant degree of inbreeding in AG1 IA populations on soybean in Brazil and this may at least partially account for the significant disequilibrium observed in these populations.
In summary, three out of the five populations showed evidence of a recombining structure. Though $R$. solani AG-1 IA has been considered to have a predominantly sexual reproductive system on soybean because sexual fruiting structures (hymenia and basidiospores) are reported as the primary inoculum on soybean fields $(22,23,31,47)$, sexual recombination did not dominate in all populations. Our overall interpretation is that populations of $R$. solani AG-1 IA from soybean in Brazil have a mixed reproductive mode, which includes (i) a considerable asexual reproductive component evident in the high clonal fractions observed, perhaps representing successful clones (or combinations of genes) that originated from sexual reproduction (67); and (ii) a significant degree of inbreeding occurring during the sexual component of the reproduction. Inbreeding does not necessarily reflect a homothallic mating system, but it could be the first hint of homothallism in this fungus.

With these findings, we postulate that novel genotypes are produced by recombination events, and that genotypes favored by selection increase in frequency through asexual reproduction within each field. The selected genotypes then spread as clones across short distances, via sclerotia or mycelium, and rarely over long distances, possibly via contaminated seed. There was no evidence for either recent bottlenecks or recent population expansions.

The risk model framework proposed by McDonald and Linde $(44,45)$ to consider the evolutionary potential of plant pathogens predicts that pathogens with low gene/genotype flow pose a lower risk than pathogens with high gene/genotype flow. Pathogens with propagules that move only short distances usually exist in small genetic neighborhoods and are expected to have lower genetic diversity and smaller effective population size. McDonald and Linde's model also proposes that pathogens that outcross pose a greater risk than inbreeding pathogens because more new genotypes will be created during the sexual cycle. But pathogens with a mixed reproductive mode would pose the highest risk of evolution because the most fit combination of alleles generated by recombination could be kept together through asexual reproduction and subsequently increase rapidly in frequency in response to selection imposed by new resistance genes or fungicides. The soybean-infecting $R$. solani AG-1 IA populations analyzed in this study exhibited restricted gene flow and a mixed reproductive mode, thus the pathogen would fall into the medium-high risk category for pathogen evolutionary potential, suggesting the need for caution when applying fungicides or breeding for major-gene resistance $(44,45)$.

\section{ACKNOWLEDGMENTS}

The first author acknowledges CAPES (Coordination for the Improvement of Higher Education Personnel, Brasilia, Brazil), for supporting her with a research assistantship during her Ph.D. Program and a leave of absence to carry out her research at ETH Zürich in 2007. This work was partially funded by an ETH grant (TH-16/06-1) to P. C. Ceresini. The statistical analyses on migration patterns were carried out using the resources of the Computational Biology Service Unit from Cornell University, which is partially funded by the Microsoft Corporation.

\section{LITERATURE CITED}

1. Adams, G. C., Jr. 1996. Genetics of Rhizoctonia species. Pages 101-106 in: Rhizoctonia Species: Taxonomy, Molecular Biology, Ecology, Pathology and Disease Control. B. Sneh, S. Jabaji-Hare, S. Neate, and G. Dijst, eds. Kluwer Academic, Dordrecht, the Netherlands.

2. Adams, G. C., Jr. 1988. Thanathephorus cucumeris (Rhizoctonia solani), a species complex of wide host range. Pages 535-552 in: Genetics of Plant Pathogenic Fungi. D. S. Ingram and P. H. Williams, eds. Academic Press, London.

3. Adams, G. C., Jr., and Butler, E. E. 1982. A reinterpretation of the sexuality of Thanatephorus cucumeris anastomosis group four. Mycologia 74:793-800. 
4. Agapow, P.-M., and Burt, A. 2001. Indices of multilocus linkage disequilibrium. Mol. Ecol. Notes 1:101-102.

5. Almeida, A. M. R., Ferreira, L. P., Yorinori, J. T., Silva, J. F. V., and Henning, A. A. 1997. Doenças da soja. In Manual de Fitopatologia: Doenças das plantas cultivadas. H. Kimati, L. Amorim, A. Bergamim Filho, L. Camargo, and J. Rezende, eds. Agronômica Ceres, São Paulo.

6. Beerli, P., and Felsenstein, J. 2001. Maximum likelihood estimation of a migration matrix and effective population sizes in $\mathrm{n}$ subpopulations by using a coalescent approach. PNAS 98:4563-4568.

7. Bennett, R. S., Milgroom, M. G., and Bergstrom, G. C. 2005. Population structure of seedborne Phaeosphaeria nodorum on New York wheat. Phytopathology 95:300-305.

8. Bolkan, H. A., and Ribeiro, W. R. C. 1985. Anastomosis groups and pathogenicity of Rhizoctonia solani isolates from Brazil. Plant Pathol. 69:599-601.

9. Ceresini, P. C., Shew, H. D., James, T. Y., Vilgalys, R. J., and Cubeta, M. A. 2007. Phylogeography of the solanaceae-infecting Basidiomycota fungus Rhizoctonia solani AG-3 based on sequence analysis of two nuclear DNA loci. BMC Evol. Biol. 13:163.

10. Ciampi, M. B., Kuramae, E. E., Fenille, R. C., Meyer, M. C., Souza, N. L., and Ceresini, P. C. 2005. Intraspecific evolution of Rhizoctonia solani AG-1 IA associated with soybean and rice in Brazil based on polymorphisms at the ITS-5.8S rDNA operon. Eur. J. Plant Pathol. 113:183-196.

11. Conab. 2007. Oitavo levantamento. Pages 11-12 in: Avaliação da safra agrícola 2006, edited by Ministério da Agricultura Pecuária e Abastecimento. Companhia Nacional de Abastecimento - Conab, Brasilia Embrapa Agropecuária Oeste, Brazil.

12. Cornuet, J. M., and Luikart, G. 1996. Description and power analysis of two tests for detecting recent population bottlenecks from allele frequency data. Genetics 144:2001-2014.

13. Cubeta, M. A., Briones-Ortega, R., and Vilgalys, R. 1993. Reassessment of heterokaryon formation in Rhizoctonia solani anastomosis group 4. Mycologia 85:777-787.

14. Cubeta, M. A., and Vilgalys, R. 1997. Population biology of the Rhizoctonia solani complex. Phytopathology 87:480-484.

15. Dupanloup, I., Schneider, S., and Excoffier, L. 2002. A simulated annealing approach to define the genetic structure of populations. Mol. Ecol. 11:2571-2581.

16. El Mousadik, A., and Petit, R. J. 1996. High level of genetic differentiation for allelic richness among populations of the argan tree (Argania spinosa [L.] Skeels) endemic to Morocco. Theor. Appl. Genet. 92:832839.

17. Embrapa. 2006. Tecnologias de produção de soja - região central do Brasil - 2007, edited by Ministério da Agricultura Pecuária e Abastecimento: Empresa Brasileira de Pesquisa Agropecuária - Embrapa Soja, Embrapa Cerrados, Embrapa Agropecuária Oeste, Brazil.

18. Excoffier, L., Laval, G., and Schneider, S. 2005. Arlequin (version 3.0): An integrated software package for population genetics data analysis. Evol. Bioinform. Online 1:47-50.

19. Excoffier, L., Smouse, P. E., and Quattro, J. M. 1992. Analysis of molecular variance inferred from metric distances among DNA haplotypes: Application to human mitochondrial DNA restriction data. Genetics 131:479-491.

20. Fearnside, P. M. 2001. Soybean cultivation as a threat to the environment in Brazil. Environ. Conserv. 28:23-38.

21. Fenille, R. C. 2001. Caracterização citomorfologica, cultural, molecular e patogênica de Rhizoctonia solani Kühn associado à soja no Brasil, Proteção de Plantas, Faculdade de Ciências Agronômicas, Universidade Estadual Paulista "Júlio de Mesquita Filho", Botucatu, Brazil.

22. Fenille, R. C., Ciampi, M. B., Kuramae, E. E., and Souza, N. L. 2003. Identification of Rhizoctonia solani associated with soybean in Brazil by rDNA-ITS sequences. Fitopatol. Bras. 28:413-419.

23. Fenille, R. C., Souza, N. L., and Kuramae, E. E. 2002. Characterization of Rhizoctonia solani associated with soybean in Brazil. Eur. J. Plant Pathol. 108:783-792.

24. Garnier-Gere, P., and Dillmann, C. 1992. A computer program for testing pairwise linkage disequilibria in subdivided populations. J. Hered. $83: 239$.

25. Goudet, J. 1995. FSTAT (Version 1.2): A computer program to calculate F-statistics. J. Hered. 86:485-486.

26. Grunwald, N. J., Goodwin, S. B., Milgroom, M. G., and Fry, W. E. 2003. Analysis of genotypic diversity data for populations of microorganisms. Phytopathology 93:738-746.

27. Guo, S. W., and Thompson, E. A. 1992. Performing the exact test of Hardy-Weinberg proportions for multiple alleles. Biometrics 48:361-372.

28. Hartl, D. L., and Clark, A. G. 1997. Principles of Population Genetics. 3rd ed. Sinauer Associates, Sunderland, MA

29. Hurlbert, S. 1971. The nonconcept of species diversity: A critique and alternative parameters. Ecology 52:577-586.
30. Igreja, A. C. M., Yokoyama, L. P., Rocha, M. B., and de Almeida, J. 1995. Cultura do arroz nos estados de Goiás e Tocantins: Aspectos socioeconômicos e tecnológicos nos sistemas de cultivo. Agricultura em São Paulo 42:65-93.

31. Jones, R. K., and Belmar, S. B. 1989. Characterization and pathogenicity of Rhizoctonia spp. isolated from rice, soybean, and other crops grown in rotation with rice in Texas. Plant Dis. 73:1004-1010.

32. Julian, M. C., Acero, J., Salazar, O., Keijer, J., and Victor, R. 1999. Mating type-correlated molecular markers and demonstration of heterokaryosis in the phytopathogenic fungus Thanatephorus cucumeris (Rhizoctonia solani) AG 1-IC by AFLP DNA fingerprinting analysis. J. Biotechnol. 67:49-56.

33. Ko, W., and Hora, F. 1971. A selective medium for the quantitative determination of Rhizoctonia solani in soil. Phytopathology 61:707-710.

34. Kuhner, M. K. 2006. LAMARC 2.0: Maximum likelihood and Bayesian estimation of population parameters. Bioinformatics 22:768-770.

35. Kuhner, M. K., and Smith, L. P. 2007. Comparing likelihood and bayesian coalescent estimation of population parameters. Genetics 175:155-165.

36. Linde, C. C., Zala, M., Paulraj, R. S. D., McDonald, B. A., and Gnanamanickam, S. S. 2005. Population structure of the rice sheath blight pathogen Rhizoctonia solani AG-1 IA from India. Eur. J. Plant Pathol. 112:113-121.

37. Liu, Y. C., Double, M. L., MacDonald, W. L., Cortesi, P., and Milgroom, M. G. 1996. Diversity and multilocus genetic structure in populations of Cryphonectria parasitica. Phytopathology 86:1344-1351.

38. Luikart, G., and Cornuet, J.-M. 1998. Empirical evaluation of a test for identifying recently bottlenecked populations from allele frequency data. Conserv. Biol. 12:228-237.

39. MacNish, G. C., Carling, D. E., and Brainard, K. A. 1993. Characterization of Rhizoctonia solani AG-8 from bare patches by pectic enzyme (zymogram) and anastomosis techniques. Phytopathology 83:922-927.

40. Manly, B. F. J. 1991. Randomization and Monte Carlo methods in biology. Chapman \& Hall, London.

41. Marchetti, M. A., and Bollich, C. N. 1991. Quantification of the relationship between sheath blight severity and yield loss in rice. Plant Dis. 75:773-775.

42. Matsumoto, M. 2002. Trials of direct detection and identification of Rhizoctonia solani AG 1 and AG 2 subgroups using specifically primed PCR analysis. Mycoscience 43:185-189.

43. Maynard Smith, J., Smith, N. H., O'Rourke, M., and Spratt, B. G. 1993. How clonal are bacteria? PNAS 90:4384-4388.

44. McDonald, B. A., and Linde, C. 2002. Pathogen population genetics, evolutionary potential, and durable resistance. Annu. Rev. Phytopathol. 40:349-379.

45. McDonald, B. A., and Linde, C. 2002. The population genetics of plant pathogens and breeding strategies for durable resistance. Euphytica 124:163-180.

46. Meirmans, P. G., and Van Tienderen, P. H. 2004. GenoType and GenoDive: Two programs for the analysis of genetic diversity of asexual organisms. Mol. Ecol. Notes 4:792-794.

47. Meyer, M. C. 2002. Caracterização de Rhizoctonia solani Kühn, agente causal da mela da soja (Glycine max [L.] Merrill), seleção de genótipos e controle químico, Proteção de Plantas, Faculdade de Ciências Agronômicas, Universidade Estadual Paulista "Júlio de Mesquita Filho," Botucatu, SP, Brazil

48. Meyer, M. C., Bueno, C. J., de Souza, N. L., and Yorinori, J. T. 2006. Effect of doses of fungicides and plant resistance activators on the control of Rhizoctonia foliar blight of soybean, and on Rhizoctonia solani AG1IA in vitro development. Crop Prot. 25:848-854.

49. Milgroom, M. G. 1996. Recombination and the multilocus structure of fungal populations. Annu. Rev. Phytopathol. 34:457-477.

50. Naito, S. 1996. Basidiospore dispersal and survival. Pages 197-206 in: Rhizoctonia Species: Taxonomy, Molecular Biology, Ecology, Pathology and Disease Control. B. Sneh, S. Jabaji-Hare, S. Neate and G. Dijst, eds. Kluwer Academic, Dordrecht, the Netherlands.

51. Naito, S. 2006. Ecological studies on teleomorphic and anamorphic stages in Rhizoctonia fungi. J. Gen. Plant Pathol. 72:400-403.

52. Nei, M. 1978. Estimation of average heterozygosity and genetic distance from a number of individuals. Genetics 89:538-590.

53. Petit, R. J., El Mousadik, A., and Pons, O. 1998. Identifying populations for conservation on the basis of genetic markers. Conserv. Biol. 12:844855.

54. Piry, S., Luikart, G., and Cornuet, J. M. 1999. BOTTLENECK: A computer program for detecting recent reductions in the effective size using allele frequency data. J. Hered. 90:502-503

55. Pritchard, J. K., Stephens, M., and Donnelly, P. 2000. Inference of population structure using multilocus genotype data. Genetics 155:945959.

56. Raymond, M., and Rousset, F. 1995. GENEPOP (Version 1.2): Population genetics software for exact tests and ecumenicism. J. Hered. 86:248-249. 
57. Rosewich, U. L., Pettway, R. E., McDonald, B. A., and Kistler, H. C. 1999. High levels of gene flow and heterozygote excess characterize Rhizoctonia solani AG-1 IA (Thanatephorus cucumeris) from Texas. Fungal Genet. Biol. 28:148-159.

58. Sato, G. S., and Moori, R. G. 2003. The impact of the biotechnology in the Brazilian seed industry. Informações Econômicas-Instituto de Economia Agrícola 33:44-53.

59. Simon, M. F., and Garagorry, F. L. 2005. The expansion of agriculture in the Brazilian Amazon. Environ. Conserv. 32:203-212.

60. Slatkin, M. 1995. A measure of population subdivision based on microsatellite allele frequencies. Genetics 139:457-462.

61. Stoddart, J. A., and Taylor, J. F. 1988. Genotype diversity: Estimation and prediction in samples. Genetics 118:705-711.

62. Taheri, P., Gnanamanickam, S., and Hofte, M. 2007. Characterization, genetic structure, and pathogenicity of Rhizoctonia spp. associated with rice sheath diseases in India. Phytopathology 97:373-383.

63. Toda, T., and Hyakumachi, M. 2006. Heterokaryon formation in Thanatephorus cucumeris anastomosis group 2-2 IV. Mycologia 98:726-736.

64. Weir, B. S. 1996. Genetic Data Analysis. 2 ed. Sinauer Associates, Sunderland, MA.

65. Weir, B. S., and Cockerman, C. C. 1984. Estimating F-statistics for the analysis of population structure. Evolution 38:1358-1370.

66. Wrather, J. A., Anderson, T. R., Arsyad, D. M., Gai, J., Ploper, L. D.,
Porta-Puglia, A., Ram, H. H., and Yorinori, J. T. 1997. Soybean disease loss estimates for the top 10 soybean producing countries in 1994. Plant Dis. 81:107-110.

67. Xu, J. 2005. Cost of interacting with sexual partners in a facultative sexual microbe. Genetics 171:1597-1604.

68. Yang, H. A., Tommerup, I. C., Sivasithamparam, K., and O'Brien, P. A. 1992. Heterokaryon formation with homokaryons derived from protoplasts of Rhizoctonia solani anastomosis group eight. Exp. Mycol. 16:268-278.

69. Yang, X. B., Berggren, G. T., and Snow, J. T. 1990. Seedling infection of soybean by isolates of Rhizoctonia solani AG-1, the causal agent of aerial blight and web blight of soybean. Plant Dis. 74:485-488.

70. Yorinori, J. T. 1998. Estratégias de controle das doenças da soja. Correio Agrícola 2:8-12.

71. Zala, M., McDonald, B. A., Bernardes de Assis, J., Ciampi, M. B., Storari, M., Peyer, P., and Ceresini, P. C. 2008. Highly polymorphic microsatellite loci in the maize- and rice-infecting fungal pathogen Rhizoctonia solani anastomosis group 1 IA. Mol. Ecol. Resour. 8:686689.

72. Zhan, J., Pettway, R. E., and McDonald, B. A. 2003. The global genetic structure of the wheat pathogen Mycosphaerella graminicola is characterized by high nuclear diversity, low mitochondrial diversity, regular recombination, and gene flow. Fungal Genet. Biol. 38:286-297. 